\title{
Noteworthy records of Ixodes schulzei (Acari: Ixodidae) on rodents from the State of Parana, southern Brazil
}

\author{
Relatos de Ixodes schulzei (Acari: Ixodidae) em roedores do Estado do Paraná, sul do Brasil \\ Valeria Castilho Onofrio ${ }^{1 *}$; Fernanda Aparecida Nieri-Bastos ${ }^{2}$; Janio dos Santos Sampaio'; \\ João Fábio Soares ${ }^{2}$; Maria José de Jesus Silva ${ }^{3}$; Darci Moraes Barros-Battesti ${ }^{4}$
}

${ }^{1}$ Laboratório de Parasitologia, Instituto Butantan, São Paulo, SP, Brasil

${ }^{2}$ Departamento de Medicina Veterinária Preventiva e Saúde Animal, Faculdade de Medicina Veterinária e Zootecnia, Universidade de São Paulo - USP, São Paulo, SP, Brasil

${ }^{3}$ Laboratório Especial de Ecologia e Evolução, Instituto Butantan, São Paulo, SP, Brasil

${ }^{4}$ Laboratório Especial de Coleçôes Zoológicas, Instituto Butantan, São Paulo, SP, Brasil

Received February 15, 2012

Accepted September 11, 2012

\begin{abstract}
Ixodes schulzei Aragão \& Fonseca is an endemic tick to Brazil and has already been reported in the northern (State of Rondonia), southeastern (States of Minas Gerais, Rio de Janeiro and Sao Paulo) and southern (State of Santa Catarina) regions, always found in association with the water rat Nectomys squamipes (Brandt). This communication records the first occurrence of this tick species in the State of Parana, southern region of Brazil, and it constitutes its first report on Akodon montensis (Thomas) and Oryzomys russatus (Wagner) hosts.
\end{abstract}

Keywords: Ixodes schulzei, new host records, distribution, Akodon montensis, Oryzomys russatus, Brazil.

\section{Resumo}

Ixodes schulzei Aragão \& Fonseca é um carrapato endêmico do Brasil e já foi relatado nas regiôes Norte (estado de Rondônia), Sudeste (estados de Minas Gerais, Rio de Janeiro e São Paulo) e Sul (estado de Santa Catarina), tendo sido encontrado sempre em associação com o rato d'água Nectomys squamipes (Brandt). Esta comunicação registra a primeira ocorrência dessa espécie de carrapato no estado do Paraná, região Sul do Brasil e constitui o primeiro relato de Akodon montensis (Thomas) e Oryzomys russatus (Wagner) como hospedeiros. Brasil.

Palavras-chave: Ixodes schulzei, novos registros de hospedeiros, distribuição, Akodon montensis, Oryzomys russatus,

The genus Ixodes Latreille, 1796 is represented by approximately 243 species (GUGLIELMONE et al., 2010). In Brazil, eight species are currently known: Ixodes amarali Fonseca, 1935; Ixodes aragaoi Foseca, 1935; Ixodes auritulus Neumann, 1904; Ixodes fuscipes Koch, 1844; Ixodes loricatus Neumann, 1899; Ixodes luciae Sénevet, 1940; Ixodes paranaensis Barros-Battesti, Arzua, Pichorim and Keirans, 2003; and Ixodes schulzei Aragão and Fonseca, 1951 (ONOFRIO et al., 2009; DANTAS-TORRES et al., 2009). A ninth species named Ixodes serrafreirei Amorim, Gazeta, Bossi and Linhares, 2003 was proposed based on the nymphal stage (AMORIM et al., 2003), but due to lack of proper description I. serrafreirei has been regarded as a nomen nudum (VENZAL et al., 2008; GUGLIELMONE et al., 2009).

\footnotetext{
*Corresponding author: Valeria Castilho Onofrio

Laboratório de Parasitologia, Instituto Butantan,

Av. Vital Brasil, 1500, CEP 05503-900, São Paulo, SP, Brasil

e-mail: valcastilho@gmail.com
}

All Ixodes species are restricted to wild hosts, primarily mammals, but two are exclusively found in birds (LABRUNA et al., 2003; ONOFRIO et al., 2006). Among these species, three are only known from females: I. amarali, I. fuscipes and I. schulzei (BARROS-BATTESTI et al., 2007). The latest species is endemic to Brazil and it has been found always in association with the water rat Nectomys squamipes (Brandt). Previous studies of life cycle under laboratory conditions suggest that I. schulzei could be a parthenogenetic species, since only female ticks were obtained from engorged nymphs (LABRUNA et al., 2003).

Barros-Battesti et al. (2007) described the immature stages and redescribed the female of I. schulzei. This species has been reported from the states of Minas Gerais, Rio de Janeiro, Sao Paulo (southeastern), Santa Catarina (southern) and Rondonia (northern) (LABRUNA et al., 2003; ARZUA et al., 2005). This communication records the first occurrence of this tick species in State of Parana, southern region of Brazil, and it constitutes its 


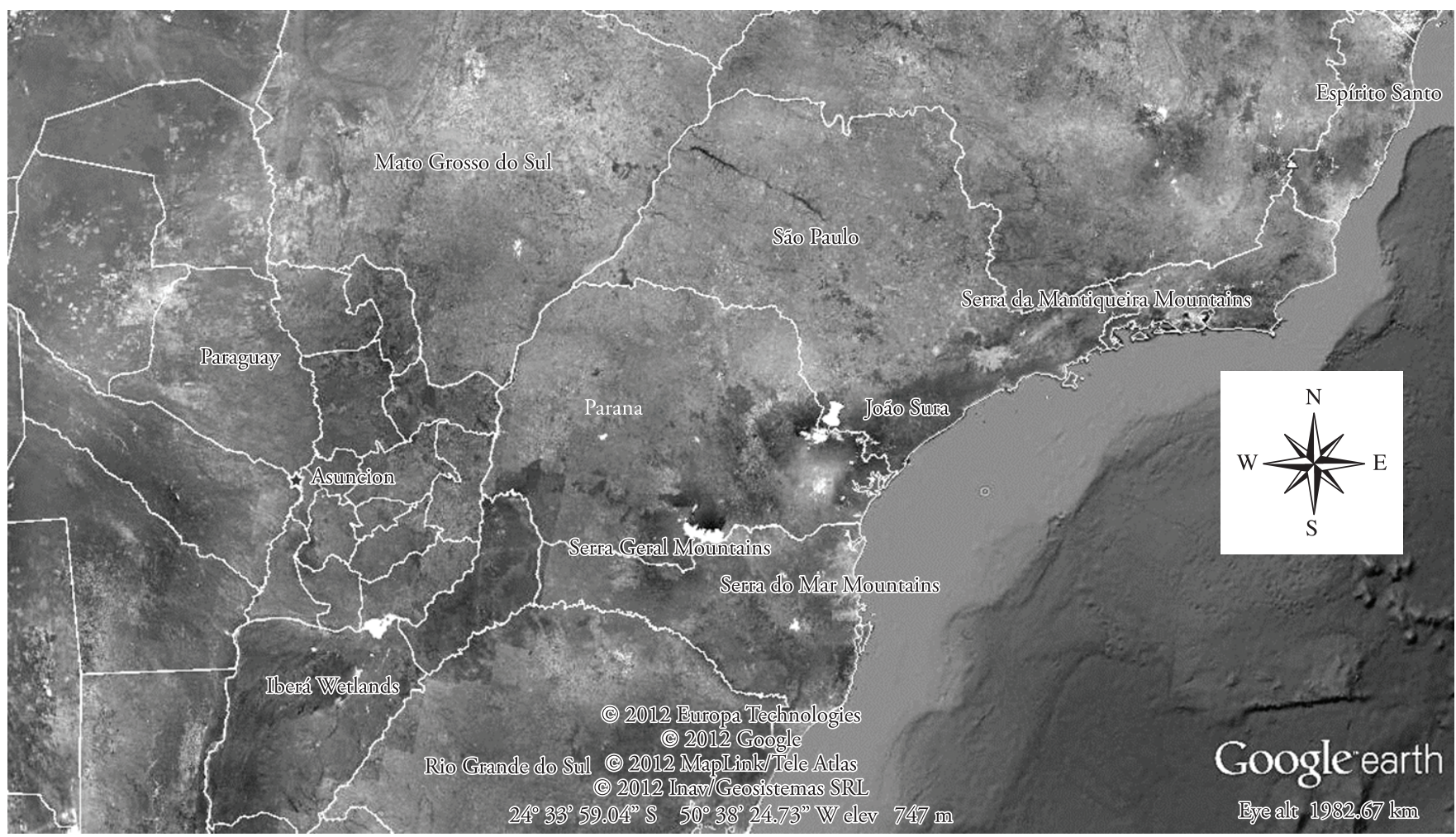

Figure 1. Map of the Brazilian south region showing the locality where Ixodes schulzei was collected.

first report on Akodon montensis (Thomas) and Oryzomys russatus (Wagner) hosts.

A total of 184 small wild mammals were collected during the development of the CNPq No. 478950/2004-7 project between March 2004 and August 2007. Marsupials were represented by five specimens of three species, while rodents were represented by 179 specimens of 10 species, included in three tribus (Akodontini, Oryzomyini and Sigmodontini). The study area is located in Joao Sura $\left(24^{\circ} 42^{\prime} 47^{\prime \prime} \mathrm{S}\right.$ and $\left.49^{\circ} 08^{\prime} 34^{\prime \prime} \mathrm{W}\right)$, municipality of Adrianopolis, State of Parana, southern Brazil (Figure 1). The rodent $A$. montensis was the most frequently trapped species followed by $O$. russatus and $N$. squamipes. On this latest rodent, 52 immature ticks of the species $I$. schulzei were collected. Two nymphs of this tick species were also found on O. russatus; they were preserved in alcohol and deposited at the Acari Collection from "Instituto Butantan" under the number IBSP 09130. In June 2009, we returned to the same area to make new collects of rodents. During 5 days, a total of 14 specimens of Akodon were trapped, but no $N$. squamipes was collected. Unexpectedly, two larvae and one nymph of $I$. schulzei were collected on A. montensis. The identification of the latter host was based on cytogenetic data $(2 \mathrm{n}=24$ e $2 \mathrm{n}=24+1 \mathrm{~B})$ according to Christoff (2007).

The nymph died after collection and it was then immersed in alcohol. Larvae were taken to the laboratory, fed on Calomys callosus Rengger, and maintained in BOD incubator at $27^{\circ} \mathrm{C}$ and 95\% RH; the same was done with the two emerged nymphs. On September 14, 2009, the engorged nymphs molted to females that were deposited at the Acari Collection under the number IBSP10336. Females were identified through illustrated keys (ONOFRIO et al., 2009).
Studies about the lifecycle of this species are in progress. In other field collection in the same area, from the $15^{\text {th }}$ to the $18^{\text {th }}$ of May 2010, two specimens of $A$. montensis were found parasitized with two and three larvae of $I$. schulzei, respectively. Larvae molted to nymphs in the laboratory, but died later and were also deposited in the Acari Collection (IBSP 10406, 10407).

The present scientific communication increases the known distribution of $I$. schulzei, recording for the first time the presence of this tick species in the State of Parana and on new hosts, $A$. montensis and $O$. russatus.

\section{Acknowledgements}

The authors are grateful to IBAMA for the license to collect. This study was supported by "Fundação de Amparo a Pesquisa do Estado de São Paulo” - FAPESP (Post-doctoral 07/53314-1 to VCO) and "Conselho Nacional de Desenvolvimento Científico e Tecnológico" - CNPq (Academic career scholarship to DMBB and doctoral fellowship to FANB).

\section{References}

Amorim M, Gazêta GS, Bossi DEP, Linhares AX. Carrapatos Ixodes (Haemixodes) serrafreirei sp. n. em roedores silvestres dos Estados do Rio de Janeiro e de São Paulo. Entomol Vect 2003; 10: 407-410.

Arzua M, Onofrio VC, Barros-Battesti DM. Catalogue of the tick collection (Acari: Ixodidae) of the Museu de História Natural Capáo da Imbuia, Curitiba, Paraná, Brazil. Rev Bras Zool 2005; 22(3): 623-632. http://dx.doi.org/10.1590/S0101-81752005000300015 
Barros-Battesti DM, Onofrio VC, Faccini JLH, Labruna MB, Arruda-Santos AD, Giacomin FG. Description of the immature stages and redescription of the female of Ixodes schulzei Aragão \& Fonseca, 1951 (Acari: Ixodidae), an endemic tick species of Brazil. Syst Parasitol 2007; 68(3): 157-166. PMid:17896185. http://dx.doi. org/10.1007/s11230-007-9100-z

Christoff AU. Contribuição a sistemática das espécies do gênero Akodon (Rodentia: Sigmodontinae) do leste do Brasil: Estudos Anatômicos, Citogenéticos e de Distiribuição Geográfica [Tese]. São Paulo: Universidade de São Paulo; 2007.

Dantas-Torres F, Onofrio VC, Barros-Battesti DM. The ticks (Acari: Ixodida: Argasidae, Ixodidae) of Brazil. Syst ApplAcarol 2009; 14(1): 30-46.

Guglielmone AA, Robbins RG, Apanaskevich DA, Petney TN, Estrada-Peña A, Horak IG. Comments on controversial tick (Acari: Ixodida) species names and species described or resurrected from 2003 to 2008. Exp Appl Acarol2009; 48(4): 311-327. PMid:19169832. http:// dx.doi.org/10.1007/s10493-009-9246-2

Guglielmone AA, Robbins RG, Apanaskevich DA, Petney TN, Estrada-Peńa A, Horak IG, et al. The Argasidae, Ixodidae and
Nuttalliellidae (Acari: Ixodida) of the world: a list of valid species names. Zootaxa 2010; 2528(6): 1-28.

Labruna MB, Silva MJN, Oliveira MF, Barros-Battesti DM, Keirans JE. New records and laboratory-rearing data for Ixodes schulzei (Acari: Ixodidae) in Brazil. J Med Entomol 2003; 40(1): 116-118. PMid:12597665. http://dx.doi.org/10.1603/0022-2585-40.1.116

Onofrio VC, Labruna MB, Barros-Battesti DM. Comentários e chaves para as espécies do gênero Ixodes. In: Barros-Battesti DM, Arzua M, Bechara GH. Carrapatos de importância médico veterinária da Região Neotropical: um guia ilustrado para identificação de espécies. São Paulo: Vox/ICTTD-3/Butantan; 2006. p. 41-51.

Onofrio VC, Barros-Battesti DM, Labruna MB, Faccini JL. Diagnoses of and illustrated key to the species of Ixodes Latreille, 1795 (Acari: Ixodidae) from Brazil. Syst Parasitol 2009; 72(2): 143-157. PMid:19115087. http:// dx.doi.org/10.1007/s11230-008-9169-z

Venzal JM, Nava S, Beldoménico PM, Barros-Battesti DM, Estrada-Peña A, Guglielmone AA. Hosts and distribution of Ixodes longiscutatus Boero, 1944 (Acari: Ixodidae). Syst Appl Acarol 2008; 13(2): 102-108. 